\title{
A Seven-Year Follow-Up of an Extremely Refractory Bipolar I Patient
}

To the Editor:

July 30, 2007

We report the 7-year follow-up of a 40-yearold married woman previously reported as an extremely refractory depressed patient ${ }^{1}$ who was repeatedly hospitalized in our department and treated with a variety of aggressive but unsuccessful treatment trials (including combinations) lasting at least 4 months each: fluoxetine $60 \mathrm{mg}$, venlafaxine $375 \mathrm{mg}$, haloperidol $40 \mathrm{mg}$, risperidone $6 \mathrm{mg}$, lithium plasma levels $1.0 \mathrm{mEq} / \mathrm{t}$, and carbamazepine plasma levels $9 \mu \mathrm{gr} / \mathrm{mL}$.

The previous case report ${ }^{1}$ concerned her temporary response to treatment with high doses of clomipramine intravenous 6 amp daily plus oral venlafaxine $225 \mathrm{mg}$ in 2000 . The patient had responded on day 15 , with a dramatic remission of symptoms, almost to normothymic state. There were no mixed or hyperthymic features present to suggest the possibility of antidepressant-induced mood switching. This had lasted for 37 days. Then, the patient had attempted suicide unsuccessfully by swallowing pills; obeying to auditory hallucinations. The mood change had been acute (within a few hours).

The patient had originally been diagnosed as suffering from dependent and borderline personality disorder and major depression with atypical features refractory to treatment, according to the Diagnostic and Statistical Manual of Mental Disorders, Fourth Edition, ${ }^{2}$ and that was the diagnosis included in the first publication of the case. ${ }^{1}$

First onset of symptoms was at 26 years of age with the form of free-floating anxiety and incomplete panic attacks, which were soon followed by major depression. Before presenting to our department, she had attempted suicide once. Her psychiatric family history was blank. She was $1 \mathrm{mg}$ dexamethasone suppression test non-suppressor (cut-off: $5 \mu \mathrm{gr} / \mathrm{dl}$ ), with blunted response to $30 \mathrm{mg}$ dexfenfluramine challenge test (cut-off: $50 \mu \mathrm{U} / \mathrm{lt}$ ). Brain single photon emission computed tomography showed increased frontal lobe regional cerebral blood flow (standard deviation: +1.5 ) and reduced (SD: -0.3 to -1.4 ) in the rest of brain areas.

The patient had no contact with our service for the last 6 years that followed the case report. During then, she received electroconvulsive therapy without any benefit, she manifested for the first time a manic episode of mild severity that lasted $~ 8$ months (2000-2001), and for the rest of the time she was depressed without any symptom-free intervals. She attempted suicide twice with pills and once by cutting her wrists. She frequently experienced mood congruent auditory hallucinations. During that period, she was treated with combinations of antipsychotics (mostly haloperidol and clozapine) and oxcarbazepine. There were also periods of alcohol and benzodiazepines abuse.

The patient presented to us again after her last suicidal attempt. The diagnosis changed to bipolar I disorder, current episode depressive. She was gradually put on quetiapine $1,500 \mathrm{mg} /$ day, lamotrigine $300 \mathrm{mg} /$ day, and topiramate $50 \mathrm{mg} /$ day. She responded well to treatment, and 20 days after treatment initiation, auditory hallucinations disappeared and mood started to improve. She was dismissed after 34 days of hospitalization with her mood at almost normothymic levels.

For the next 7 months, the patient was normothymic with no residual symptoms. This was 
the second true normothymic interval (after the $\mathbf{3 7}$ days that followed clomipramine infusions) since the onset of her disease at 26 years of age, that is 14 years ago. Her body mass index at admission was 51.11 (weight: $146 \mathrm{kgr}$, height: $169 \mathrm{~cm}$ ) and fell to $46.56(133 \mathrm{kgr})$ at release. Seven months later, her body mass index was 38.51 ( $110 \mathrm{kgr}$ ).

The authors feel that the publication of the follow-up of this case will be of help in the clinical understanding of complex and refractory cases of depression often encountered in clinical practice.

\section{Sincerely,}

Konstantinos N. Fountoulakis, MD, PhD

Stamatia Magiria, MD

Melina Siamouli, MD

Panagiotis Panagiotidis, MD

loannis Nimatoudis, MD, PhD

Apostolos lacovides, MD, PhD

George S. Kaprinis, MD, PhD

\section{REFERENCES}

1. Fountoulakis $K N$, lacovides A, St Kaprinis $G$. Combined oral venlafaxine and intravenous clomipramine-A: successful temporary response in a patient with extremely refractory depression. Can J Psychiatry. 2004;49:73-74.

2. Diagnostic and Statistical Manual of Mental Disorders, 4th ed. Washington, DC: America Psychiatric Association; 1994.

Dr. Fountoulakis is assistant professor of psychiatry, Dr. Magiria is research associate, Dr. Siamouli is research associate, Dr. Panagiotidis is research associate, Dr. Nimatoudis is associate professor of psychiatry, Dr. lacovides is professor of psychiatry, and Dr. Kaprinis is head professor of psychiatry, all in the 3rd Department of Psychiatry at Aristotle University of Thessaloniki in Greece.

Disclosure: The authors have received support concerning travel and accommodation expenses from various pharmaceutical companies in order to participate in medical congresses. Dr. Fountoulakis receives honoraria from AstraZeneca, Eli Lilly, and Janssen-Cilag; and a research grant from Pfizer Foundation.

Please send letters to the editor to: CNS Spectrums, c/o Eric Hollander, MD, 333 Hudson St., 7th Floor, New York, NY 10013; E-mail: vi@mblcommunications.com.

\title{
Now Available Online at www.cnsspectrums.com
} CME-ACCREDITED SUPPLEMENT An expert review of clinical challenges in psychiatry

\section{The Complexity of ADHD:}

Diagnosis and Treatment of the Adult Patient with Comorbidities

\author{
by Jeffrey H. Newcorn, MD, Margaret Weiss, MD, PhD, and Mark A. Stein, PhD, ABPP
}

To request a published supplement, pleasee-mail ks@mblcommunications.com

Supported by an educational grant from Eli Lilly. 


\section{AlZheimer's Disease SUMMIT}

Translating Research Advances Into Clinical Practice

\section{es Save The Date:}

Saturday, May 3, 2008 - Washington, DC 8:00 a.m. $-7: 00$ p.m.

\section{Program Chairs:}

JefFrey L. Cummings, MD, and Pierre N. Tariot, MD

\section{PROGRAM SESSIONS INCLUdE:}

- Advances in Clinical ASSESSMENT

- Advances in Neuroimaging AND BIOMARKERS
- Current Alzheimer Therapy: Best PraCtices

- The Future of Alzheimer THERAPEUTICS

For more information, please call 212-328-0800 or visit www.adsummit2008.com

\section{PRIMARY PSYCHIITRY CNS SPECTRUMS PsychiatryWeekly}

A Global Commitment to Advancing CNS Science, Clinical Practice, and Evidence-Based Medicine 


\section{AlZHEIMER'S DISEASE SUMMIT}

Translating Research Advances Into Clinical Practice

\section{es Save The Date:}

Saturday, May 3, 2008 - Washington, DC 8:00 a.m. $-7: 00$ p.m.

\section{PROGRAM Chairs:}

JeFFrey L. Cummings, MD, AND PierRe N. TARIOT, MD

\section{PROGRAM SESSIONS INCLUdE:}

- Advances in Clinical ASSESSMENT

- Advances in Neuroimaging AND BIOMARKERS
- Current Alzheimer Therapy: Best Practices

- The Future of Alzheimer Therapeutics

\section{For more information, please call 212-328-0800 or visit www.adsummit2oo8.com}

\section{PRIMARY PSYCHIATRY \\ R-m

